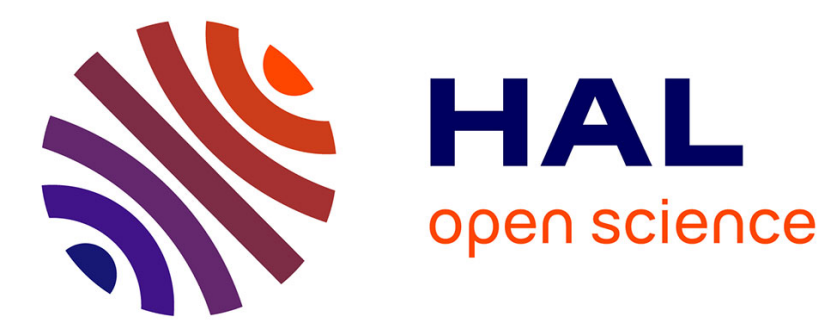

\title{
Trees to control weeds in pearl millet
}

\author{
Nuhu A. Gworgwor
}

\section{To cite this version:}

Nuhu A. Gworgwor. Trees to control weeds in pearl millet. Agronomy for Sustainable Development, 2007, 27 (2), pp.89-94. hal-00886334

\section{HAL Id: hal-00886334 https://hal.science/hal-00886334}

Submitted on 1 Jan 2007

HAL is a multi-disciplinary open access archive for the deposit and dissemination of scientific research documents, whether they are published or not. The documents may come from teaching and research institutions in France or abroad, or from public or private research centers.
L'archive ouverte pluridisciplinaire HAL, est destinée au dépôt et à la diffusion de documents scientifiques de niveau recherche, publiés ou non, émanant des établissements d'enseignement et de recherche français ou étrangers, des laboratoires publics ou privés. 


\title{
Trees to control weeds in pearl millet
}

\author{
Nuhu A. GWORGWOR*
}

Department of Crop Production, Faculty of Agriculture, University of Maiduguri, Borno state, Nigeria

(Accepted 28 September 2006)

\begin{abstract}
This study shows that growing trees represents a sustainable and efficient alternative to control weeds in millet. A survey was conducted on farmers' fields in September 1998 at the end of the rainy season in Maiduguri in the semi-arid zone of Nigeria to assess the potential of the Faidherbia albida tree for the control of the Striga hermonthica weed in millet. A random survey was carried out in four locations on the farmers' fields. The results show that $F$. albida trees could completely control S. hermonthica weeds occuring in millet under the tree canopy. Indeed, no single Striga emergence was observed under all trees surveyed, while the adjacent crops outside the tree canopies were seriously infested with S. hermonthica, causing reduction in plant growth of $76.5 \%$, panicle length of $23.8 \%$ and millet panicle yield of $171.3 \%$. Furthermore, plant performance under the tree canopies was very high, as plant height was increased by $80.0 \%$, stem diameter by up to $15.9 \%$, panicle length by $34.4 \%$ and panicle yield by $298.6 \%$ as compared with the Striga-infested plants outside the tree canopy. Plants within the 6-15 m area away from the tree trunk performed better than the 0-5 $\mathrm{m}$ area. The implication of these results in relation to Striga control in the semi-arid region of West Africa is discussed.
\end{abstract}

Faidherbia albida / Striga hermonthica / control / millet / semi-arid / Nigeria

\section{INTRODUCTION}

The food production potential of the semi-arid region of West Africa, especially cereals, e.g. sorghum (Sorghum bicolour (L.) Moench), millet (Pennisetum glaucum (L.)) R. Br. and maize (Zea mays L.), has seriously been reduced due to the parasitic weed Striga hermonthica. Pearl millet is a major food crop grown in the semi-arid region of West Africa. All over West Africa in the drier northern part, above the latitude $10^{\circ} \mathrm{N}$, where cereals are grown S. hermonthica is often a very serious production constraint. Even newly open farm lands devoted to millet production are often seen with heavy infestation of Striga. In areas where there is too little crop rotation, severe cases of Striga infestation are more noticeable, often resulting in total crop failure (Last, 1961; Bebawi and Farah, 1981; Abbasher, 1994). Often, farms with intolerable levels of Striga infestation are abandoned by farmers; for example, according to a recent survey in the northern Yobe state of Nigeria, which lies in the semi-arid zone, $69.2 \%$ of farmers have experienced a very severe field infestation by Striga and have abandoned their fields (Gworgwor et al., 2000).

Great yield losses can occur in cereal crops due to Striga infestation; for example, grain yield losses in sorghum may reach up to $70 \%$ as a result of Striga infestation (Doggett, 1984; Parker, 1984; Gworgwor and Weber, 1991, Gworgwor et al., 2001). At this time, Striga represents the largest biological constraint for grain production in Africa. According to Sauerborn (1991), the cultivated areas actually infested by Striga in Africa are estimated at 21 million hectares. The overall loss in grain production amounts to 4.1 million tons. The

* Corresponding author: ngworgwor@yahoo.com loss of revenue from sorghum, pearl millet and maize due to the parasite infection could total 2.9 billion \$ US. In India, Hosmani (1978) reported that Striga causes losses in grain yield of cereals from 15 to $100 \%$.

One of the most successful and promising control measures is the adequate application of mineral nitrogenous fertilisers. It has been reported by several researchers that high or adequate application of nitrogen in cereals plays a great role in reducing or delaying Striga infestation in cereals and increasing grain yield (Bebawi, 1981; Wilson and Parker, 1984; Pesch and Pieterse, 1982; Sherif and Parker, 1986; Carson, 1988; Gworgwor and Weber, 1990, 1991). However, often the poor resource-based African farmer finds it difficult to procure sufficient mineral fertilisers, apart from being expensive for him. One of the cheapest means of improving his soil fertility, which could effectively reduce or eliminate Striga infestation, is the use of the F. albida tree in an agroforestry practice on his farm. Faidherbia albida is well spread all over the dried region of West Africa, and East and South Africa where there is a long dry season (Giffard, 1964), which equally favours Striga survival. Weber (1978) indicates that F. albida can be found anywhere millet can grow. It is the fastest growing savannah tree in Africa (Wickens, 1969). It usually grows into a tree with maximum height of $25 \mathrm{~m}$ with a large spreading crown. It is drought-resistant due to its extensive root system that reaches an adequate moisture level.

The tree has the characteristic of shedding its foliage at the start of the rainy season and coming into leaf in the dry season. This "inverted" phenology means that its presence in farmers' fields does not interfere with agriculture, but gives it enormous value for sustaining soil fertility and in addition, in 
providing animal fodder, fuel wood and building materials in the long dry season. These qualities have been known for generations among a number of African people who have deliberately encouraged it, creating a kind of parkland (Wood, 1989). Matured F. albida can improve soil fertility by increasing by more than double the organic matter, nitrogen, phosphorus and exchangeable cations ( $\mathrm{Ca}, \mathrm{K}, \mathrm{Mg}$ and $\mathrm{Na}$ ). The soil $\mathrm{pH}$ is almost neutral, while the CEC values are also high, confirming the well-buffered fertile status of the soil (Charreau and Vidal, 1965; Radwanski and Wickens, 1967; Dancette and Poulain, 1968; Charreau and Nicou, 1971; Saka and Bunderson, 1989). In addition, it improves the microclimate by the increase in relative humidity, reduced extreme temperature, potential evapotranspiration, wind velocity and increased volume of rainfall, which favours the growth of the crops grown under it, such as millet (Wood, 1989).

Thus, one practical use of F. albida in agroforestry is its benefit in restoring soil nutrients, whereby practically all over the semi-arid zone of Nigeria where the tree is found in farmers' fields, millet, sorghum and maize are normally grown under it (Gworgwor, 1988). The growth of such crops is usually more vigorous under the tree canopy than the surrounding crops outside the tree canopy (Poschen, 1986). Millet and sorghum grain yields under the tree in the Sahel are 50 to $250 \%$ higher than adjacent areas away from the tree, while groundnut yields are 35 to $100 \%$ higher (Charreau and Vidal, 1965; Dancette and Poulain, 1968; Felker, 1978). An average maize grain yield increase of $76 \%$ has been reported by Poschen (1986) under the trees in Ethiopia, but with a range of 0 to $600 \%$ increases. By making these observations about the agroforestry practice of the tree in the field, a field survey was carried out during the 1998 rainy season around Maiduguri metropolis with the objective of assessing the role of $F$. albida in controlling $S$. hermonthica in millet.

\section{MATERIALS AND METHODS}

\subsection{Survey site}

The survey carried out on farmers' fields was done between 13th and 29th September, 1998 in Maiduguri $\left(11^{\circ} 51^{\prime} \mathrm{N}\right.$; $\left.13^{\circ} 15^{\prime} \mathrm{E}\right)$, Nigeria. The mean annual rainfall lies between 350 and $500 \mathrm{~mm}$ with a mean maximum temperature of $32-35^{\circ} \mathrm{C}$. The rainfall cycle is very short, from June to September, and the distribution is very erratic. The soil of the area surveyed is a sandy loam with $67 \%$ sand, $14 \%$ silt and $18 \%$ clay and has a water-holding capacity of $35.84 \%$ with a very low organic matter $(0.415 \%)$ and low percent total N (0.075) (Rayar, 1983). Most of these fields were not applied with any form of fertilisers due to the difficulties of fertiliser procurement and high costs, as testified by the farmers seen and interviewed on their farms during the course of the survey. The tree canopy size (diameter) of all the surveyed areas ranges from $26.0 \mathrm{~m}$ to $30.0 \mathrm{~m}$ with a mean canopy diameter of $28.6 \mathrm{~m}$. These are large trees with an average height of $23 \mathrm{~m}$ and $4.5 \mathrm{~m}$ girth.

\subsection{Survey and experimental procedure}

Four sites were surveyed around Maiduguri metropolis where the population of $F$. albida is considerably high (Gworgwor, 1988). The farms surveyed were all millet farms, as it is the only cereal crop popularly adapted and grown in this region where rainfall is a limiting factor for crop production. These are north, south, east and west coordinates of the town. Each coordinate was taken as a replicate site. There were five positions or areas per replicate, and these were: $0-5 \mathrm{~m}, 6-$ $10 \mathrm{~m}$ and 11-15 $\mathrm{m}$ distances measured from the base of the F. albida tree, outside the tree canopy Striga-free (outside Striga-free), and Striga-infested plants outside the tree canopy (outside - Striga-infested). These positions/areas were considered laid out in a complete block design (CBD). Ten F. albida trees were selected at random within an area of $5 \times 3 \mathrm{~km}$ $\left(15 \mathrm{~km}^{2}\right)$ in every replicate (site). Under and outside each tree, measurements of data were taken per the positions/areas mentioned above.

The parameters measured include plant height $(\mathrm{cm})$, panicle length $(\mathrm{cm})$, stem and panicle diameters $(\mathrm{mm})$, Striga count per plant stand $\left(\mathrm{m}^{2}\right)$, panicle weight per plant $(\mathrm{g})$, crop vigour and weed cover scores. Each of these parameters was measured by choosing 10 plants within the treatment areas at random, except for crop vigour and weed cover scores, where visual assessment was done per the whole treatment area under each tree using the scale of $0-10$; where 0 denotes complete crop kill and no weed cover, and 10 denotes full vigorous plant growth and full weed cover, respectively. All values for each parameter recorded were averaged according to treatments and replicates and were subjected to statistical analysis of variance (ANOVA) according to Gomez and Gomez (1984).

\section{RESULTS AND DISCUSSION}

In the semi-arid region of West Africa where the land is fragile due to constant pressure by the increasing human and animal population coupled with intense land cultivation and desert encroachment, the conditions obviously favour the severe infestation of the cereal fields by $S$. hermonthica (Gworgwor et al., 2001). This warrants a clear need to develop or improve the technologies that could maintain agricultural and environmental sustainability. The widespread and systematic integration of $F$. albida offers an attractive possibility for achieving this goal in the semi-arid region of West Africa. More so, when $F$. albida could completely control $S$. hermonthica on cereal fields and tremendously improve their yields. This could be due to the improved soil fertility conditions, which obviously suppress or eliminate Striga infestation and improve yields of cereal crops (Gworgwor and Weber, 1991). The major objective of inter-planting $F$. albida with crops is to improve crop productivity through increased soil fertility, which could contribute to the reduction or elimination of Striga infestation and ensure the sustainability of cropping activities for smallholder farmers. 
Table I. Effect of Faidherbia albida canopy on Striga infestation, plant height, stem diameter and Striga count plant ${ }^{-1} \mathrm{~m}^{-2}$ on millet grown in Maiduguri, Nigeria.

\begin{tabular}{lccc}
\hline Treatment & Plant height $(\mathrm{cm})$ & Stem diameter $(\mathrm{mm})$ & ${\text { Striga } \text { count }^{-2}}^{-2}$ \\
\hline $0-5 \mathrm{~m}$ & 228.8 & 10.9 & $0.0(1.0)^{1}$ \\
$6-10 \mathrm{~m}$ & 282.5 & 14.9 & $0.0(1.0)$ \\
$11-15 \mathrm{~m}$ & 271.3 & 14.5 & $0.0(1.0)$ \\
Outside - Striga-free & 232.4 & 12.1 & $0.0(1.0)$ \\
Outside - Striga-infested & 154.7 & 8.8 & $73.0(8.3)$ \\
S.E. $( \pm)$ & 16.10 & 0.63 & 0.78 \\
L.S.D. $(P=0.05)$ & 34.31 & 1.34 & 1.66 \\
\hline
\end{tabular}

${ }^{1}$ Numbers in parenthesis are transformed $\sqrt{1+X}$ number of Striga millet stand ${ }^{-1} \mathrm{~m}^{-2}$.

\subsection{Plant growth parameters}

The mean plant height of millet differed highly significantly among the treatments (Tab. I). The plants under $F$. albida within the areas of 6-10 $\mathrm{m}$ and $11-15 \mathrm{~m}$ away from the trunk of the tree had comparable plant height, but both areas had significantly taller plants compared with the $0-5 \mathrm{~m}$ area and Striga-free and Striga-infested plants outside the tree canopy. The plants within the areas of $0-5 \mathrm{~m}$ and Striga-free outside the tree canopy had similar plant height, but both areas had significantly taller plants than the Striga-infested plants outside the tree canopy. The tree canopy influence on millet height dramatically increased plant height by $76.1 \%, 80.0 \%$ and $79.8 \%$ for the $0-5 \mathrm{~m}, 6-10 \mathrm{~m}$ and $11-15 \mathrm{~m}$ areas away from the base of the tree compared with the Striga-infested plants outside the tree canopy, respectively. Similarly, the tree canopy improved plant height by $53.0 \%$ and $51.2 \%$ for the 6$10 \mathrm{~m}$ and $11-15 \mathrm{~m}$ areas compared with the Striga-free plants outside the tree canopy. The 0-5 $\mathrm{m}$ area under the tree canopy, however, decreased plant height by $1.6 \%$ compared with the Striga-free plants outside the tree canopy, although this was not significant (Tab. I). Striga infestation, however, decreased plant growth by $76.5 \%$ compared with the Striga-free plants outside the tree canopy (Tab. I).

Plants under the tree canopy within the 6-10 $\mathrm{m}$ and 11$15 \mathrm{~m}$ areas had similar stem diameter, but the plants were significantly more robust and thicker than in the $0-5 \mathrm{~m}$ area under the tree canopy and the plants outside the tree canopy, both Striga-free and Striga-infested (Tab. I). The plants outside the tree canopy which were Striga-free had significantly thicker stems compared with the Striga-infested plants outside the tree canopy and in the $0-5 \mathrm{~m}$ area under the tree canopy (Tab. I). Striga infestation reduced stem diameter by $11.7 \%$ compared with the Striga-free plants, which was significant. The tree canopy improved stem diameter by $11.1 \%, 15.9 \%$ and $15.9 \%$ for the $0-5 \mathrm{~m}, 6-10 \mathrm{~m}$ and $11-15 \mathrm{~m}$ areas, respectively, compared with the Striga-infested plants outside the tree canopy. The plants within the 6-10 $\mathrm{m}$ and $11-15 \mathrm{~m}$ areas under the tree canopy also had an increased stem diameter by $12.4 \%$ and $12.4 \%$, respectively, than the Striga-free plants outside the tree canopy (Tab. I).

The crop vigour of millet shows that under the tree canopy, plants within the $11-15 \mathrm{~m}$ area had significantly vigorous growth compared with the 0-5 $\mathrm{m}$ and 6-10 $\mathrm{m}$ areas (Fig. 1). The plants within the $6-10 \mathrm{~m}$ and $11-15 \mathrm{~m}$ areas had significantly better crop growth compared with the $0-5 \mathrm{~m}$ area under the tree canopy and plants outside the tree canopy, either Striga-free or infested.

The significant increase in millet height, crop vigour and stem diameter could be attributed probably to the effect of the improved soil and microclimate on crop growth under the tree canopy. Several researchers within the Sahel and Sudan zones of West Africa have reported the improvement of plant growth due to improved soil fertility and microclimate (Charreau and Vidal, 1965; Charreau and Nicou, 1971; Dancette and Poulain, 1968; Radwasnski and Wickens, 1967). Similarly, an improved soil fertility effect under F. albida in Malawi has been reported by Saka and Bunderson (1989), where organic matter, nitrogen, phosphorus and exchangeable cations were all high compared with soils outside the tree canopy of $F$. albida. The soil $\mathrm{pH}$ was almost neutral, while the CEC values were also high, confirming the well-buffered fertile status of the soil.

Since F. albida is bare of leaves during the growing rainy season, sufficient light penetrates through to the crops beneath the canopy for normal photosynthesis. The partial shading produced by the tree branches, coupled with the leaf mulch on the ground, reduces heat stress and evapotranspiration, which contributes to the early season survival of crops and improved crop growth and yields. Thus, crop growth under F. albida is favourable because of these factors and improved soil conditions.

The reduced plant growth and vigour within the $0-5 \mathrm{~m}$ area from the base of the tree could be attributed to severe shading by the big trunk of the tree. The farmer could thus utilise this area under the tree by planting vegetables such as okra (Abelmuschus esculentus), aubergine (Solanum melongena), garden egg (Solanum incanum), cucumbers (Cucumis sativa), pumpkins (Cucurbita spp.) or peppers (Capsicum spp.).

\subsection{Yield components}

Millet panicle length was highly significantly affected by the different treatments (Fig. 2). Plants under the tree canopy within the areas of 6-10 $\mathrm{m}$ and $11-15 \mathrm{~m}$ had similar panicle length, but both areas had significantly longer panicles than the 


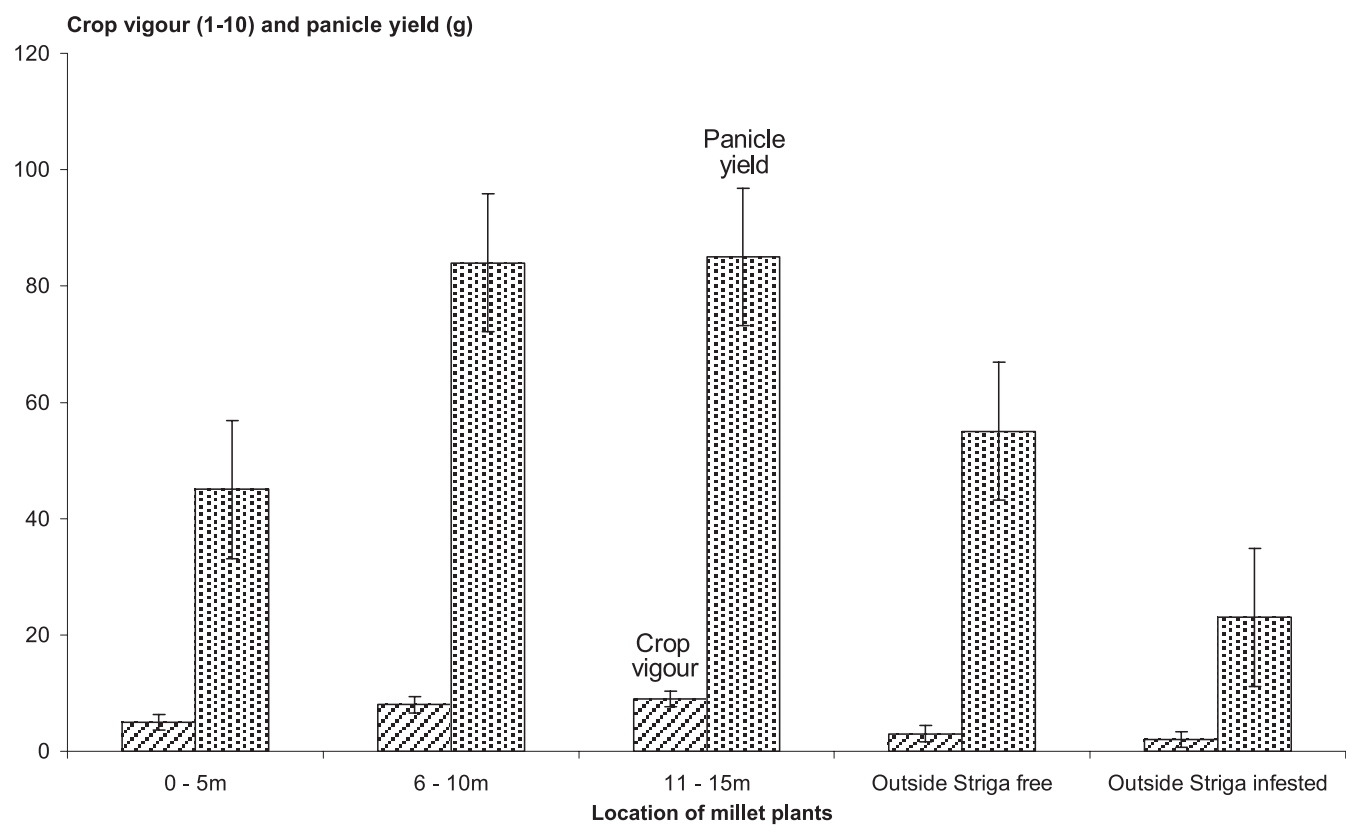

Figure 1. Effect of the Fadherbia albida tree on the crop vigour score and panicle yield of millet grown in Maiduguri, Nigeria.

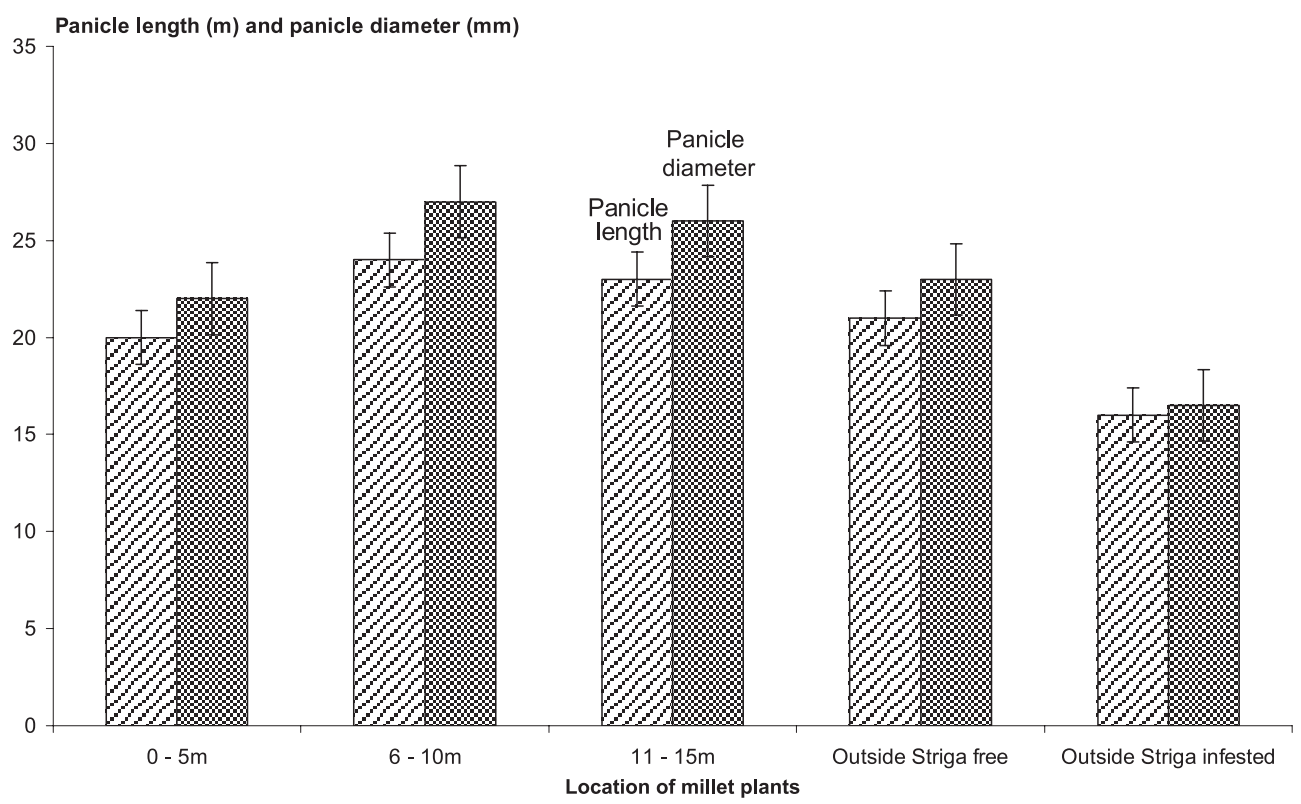

Figure 2. Effect of Fadherbia albida on the panicle length and panicle diameter of millet grown in Maiduguri, Nigeria.

0-5 $\mathrm{m}$ area under the tree canopy and outside the tree canopy of both Striga-free and infested plants (Fig. 2). Plants under the tree canopy within the $0-5 \mathrm{~m}$ area and Striga-free outside the tree canopy had similar panicle length, but both had significantly longer panicles than the Striga-infested plants outside the tree canopy (Fig. 2).

As a result of the influence of the tree canopy, which eliminated Striga infestation, the panicle length of millet was increased by $19.6 \%, 34.4 \%$ and $33.6 \%$ for the $0-5 \mathrm{~m}, 6-$ $10 \mathrm{~m}$ and 11-15 $\mathrm{m}$ areas, respectively, compared with the Striga-infested plants outside the tree canopy. The panicles of plants outside the canopy infested with Striga were reduced by $23.8 \%$ compared with the Striga-free plants (Fig. 2). Furthermore, the favourable microclimate of the tree canopy improved panicle length of millet by $13.9 \%$ and $12.9 \%$ for the 6-10 $\mathrm{m}$ and 11-15 $\mathrm{m}$ areas, respectively, compared with the Striga-free plants outside the canopy. The $0-5 \mathrm{~m}$ area reduced panicle length by $5.4 \%$ compared with the Striga-free plants (Fig. 2).

The panicle diameter of millet was significantly increased under the tree canopy for all the treatment areas compared with the outside plants, either Striga-free or infested (Fig. 1). 
However, under the tree itself, panicle diameter differed significantly. Panicles within the areas of 6-10 $\mathrm{m}$ and $11-15 \mathrm{~m}$ had comparable panicle diameter, while both areas produced significantly thicker panicles than the $0-5 \mathrm{~m}$ area (Fig. 2). Striga infestation significantly reduced panicle diameter compared with the Striga-free plants outside the tree canopy.

\subsection{Striga infestation and other weeds}

Under the whole tree canopies surveyed it was shown that there was no single emergence of Striga plants on millet, while immediately outside the canopies there was a high Striga infestation per $\mathrm{m}^{2}$ of every infested plant stand (Tab. I).

The most common weed observed under the tree canopies was Commelina benghalensis, while others included Borreria laevis and Vernonia spp., with Digitaria ciliaris found at the tree canopy edges. In all the four sites surveyed, the intensity of weed cover under the tree canopy had a range of 4.3 at one site and as high as 9.6 at another site, while the open field outside the tree canopy had a mean weed cover score of 1.3. Most of the fields were weeded only twice by the farmers.

Under the tree canopies, there was a complete elimination of $S$. hermonthica infestation of millet plants. This could probably be due to the improved soil fertility status and other soil microorganisms under the tree canopy which might have interfered with the germination of Striga and subsequent attachment to the plants (Pesch and Pieterse, 1982; Farina et al., 1985; Gworgwor and Weber, 1990, 1991, 2003).

\subsection{Panicle yield}

The weight per panicle was significantly affected by the treatment areas (Fig. 1). Under the tree canopy the 6-10 $\mathrm{m}$ and 11-15 m treatment areas had comparable high panicle weight, but both produced significantly higher panicle yield than the $0-5 \mathrm{~m}$ area. The panicle yield of the $0-5 \mathrm{~m}$ area under the tree was, however, comparable with the panicle yield of plants outside the tree canopy, which were Striga-free. All the areas under the tree canopy and Striga-free plants outside the tree canopy had significantly higher panicle yield compared with the Striga-infested plants outside the tree canopy (Fig. 1).

Panicle weight was increased by $106.9 \%, 291.5 \%$ and $298.6 \%$ for the $0-5 \mathrm{~m}, 6-10 \mathrm{~m}$ and $11-15 \mathrm{~m}$ areas, respectively, under the tree canopy compared with the Striga-infested plants outside the tree canopy. Striga infestation, however, reduced panicle yield by $171.3 \%$ compared with the Strigafree plants outside the tree canopy. The plants under the tree canopy had significantly increased panicle weight by $44.3 \%$ and $46.9 \%$ for the $6-10 \mathrm{~m}$ and $11-15 \mathrm{~m}$ areas, respectively, compared with Striga-free plants outside the tree canopy. However, the 0-5 $\mathrm{m}$ area reduced panicle yield by $23.7 \%$ compared with the Striga-free plants outside the tree canopy (Fig. 1).

These improvements in plant yield performance could be due to the favourable improved soil fertility which eliminates
Striga infestation and enhances plant growth through possibly increased microbial activities which aerate and mobilise soil nutrients, making them available to the plants, and by creating a conducive microclimate compared with the harsh dry weather of the semi-arid region. Earlier reports have shown that millet and sorghum yields under the tree in the Sahel of West Africa were $50 \%$ to $250 \%$ higher than adjacent areas outside the tree canopies, while groundnut yields were $35 \%$ to $100 \%$ higher (Charreau and Vidal, 1965; Dancette and Poulain, 1968). Average maize yield increases of $76 \%$ have also been reported by Poschen (1986) under the tree in Ethiopia, and Saka and Bunderson (1989) have reported a similar increase in yield of maize in Malawi.

However, the performance of the millet plant under the tree canopy within the 6-15 $\mathrm{m}$ area performed significantly better than the $0-5 \mathrm{~m}$ area, as panicle length of millet was reduced by $5.4 \%$ and panicle weight by $23.7 \%$ within the $0-5 \mathrm{~m}$ area. This could be due to excessive shading of the plants immediately near the tree trunk as most of the trunks were really huge. The farmer could, however, avoid planting his millet crop within this area $(0-5 \mathrm{~m})$, but instead plant vegetables.

\section{CONCLUSION}

In conclusion, this research revealed that the tree $F$. albida has a great potential in the management and effective control of $S$. hermonthica in the semi-arid zone of Nigeria where it is popularly grown. However, this finding is inconclusive as further investigation on how F. albida works at controlling Striga seems to be imperative. In particular, the basic areas that need to be investigated include the effect of shading, microclimate, soil fertility, microbial activities and allelopathy. Furthermore, its proper integration into the farming system needs proper investigation for effective management by farmers.

\section{REFERENCES}

Abbasher A.A. (1994) Micro-organisms associated with Striga hermonthica and possibilities of their utilization as biological control agents, Ph.D. Thesis, University of Hohenheim, Germany, p. 144.

Bebawi F.F. (1981) Response of sorghum cultivars and Striga population to nitrogen fertilization, Plant Soil 59, 261-267.

Bebawi F.F., Farah A.F. (1981) Effect of nitrophoska and atrazine on relations between Sorghum bicolour and Striga hermonthica, Exp. Agr. $17,425-430$.

Carson A.G. (1988) Development and testing of control package for Striga hermonthica on small-scale holdings in the Gambia, Trop. Pest Manage. 34, 97-101.

Charreau C., Nicou R. (1971) L'amélioration du profil cultural dans les sols sableux et sabloagileux de la zone tropicale sèche OuestAfricaine et ses incidences agronomiques, Agr. Trop. 76, 565-631.

Charreau C., Vidal P. (1965) Influence de l'Acacia albida Del. sur le sol, la nutrition minerale et les rendements des mils Pennisetum au Sénégal, Agr. Trop. 20, 600-625.

Dancette C., Poulain J.F. (1968) Influence de l'Acacia albida sur les facteurs pédoclimatiques et rendements des cultures, Sols Afr. 13, 197-239. 
Doggett H. (1984) Striga: Biology and Control, An overview, in: Ayensu E., Dogget H., Keynes H.D., Marton-Lefevre J., Musselman L.J., Parker C., Pickering A. (Eds.), ICSU Press, Paris, pp. 27-36.

Farina M.P.W., Thomas P.E.L., Channon P. (1985) Nitrogen, phosphorus and potassium effects on the incidence of Striga asiatica (L.) Kuntze in maize, Weed Res. 24, 443-447.

Felker P. (1978) State of the Art: Acacia albida as a complementary permanent intercrop with annual crops. Proposal under contract for USAID, Riverside, Dept. of Soil and Envir. Sci., University of California.

Giffard P.L. (1964) Les possibilités de reboisement en Acacia albida au Sénégal, Bois Forest Trop. 95, 21-32.

Gomez K.A., Gomez A.A. (1984) Statistical Procedures for Agricultural Research, John Wiley \& Sons, New York.

Gworgwor N.A. (1988) Agroforestry in millet and sorghum based cropping systems in the semi-arid zone of Nigeria: The case of Acacia albida Del, in: Proceedings Farming Systems Research/Extension Symposium, Farming Systems Paper Series No. 17, 349-356.

Gworgwor N.A., Weber H.C. (1990) Striga hermonthica (Del.) Benth. control in sorghum, in: Proceedings 14th Columa Conference, Int. Meet. Weed Control, Versailles, France, 1, pp. 387-395.

Gworgwor N.A., Weber H.C. (1991) Effect of N-application on sorghum growth, Striga infestation and the osmotic pressure of the parasite in relationship to the host, J. Plant Physiol. 139, 194-198.

Gworgwor N.A., Anaso A.B., Gwary D.M. (2000) Occurrence of Striga species and mistletoes in the semi-arid zone of Nigeria, J. Arid Agr. 10, 29-35.

Gworgwor N.A., Ndahi W.B., Weber H.C. (2001) Parasitic weeds of North-eastern Nigeria: a new potential threat to crop production, Proceedings of British Crop Protection Council (BCPC) - Weeds 2001 Conference, Brighton, UK, pp. 181-186.

Gworgwor N.A., Weber H.C. (2003) Arbuscular Mycorrhizal (AM) fungi-parasite-host interaction for the control of Striga hermonthica (Del.) Benth. in sorghum (Sorghum bicolour (L.) Moench), Mycorrhiza 13, 277-281.

Hosmani M.M. (1978) Striga - a noxious parasitic weed, University of Agricultural Sciences, Dhawar, India.
Last F.T. (1961) Direct and residual effect of Striga control treatments on sorghum yields, Trop. Agr. (Trinidad) 38, 49.

Parker C. (1984) The influence of Striga species on sorghum under varying nitrogen fertilization, in: Proceedings 3rd International Symposium on Parasitic Weeds, Aleppo, Syria, pp. 90-98.

Pesch J.C., Pieterse A.H. (1982) Inhibition of germination of Striga by means of urea, Experientia 38, 559-560.

Poschen P. (1986) An evaluation of Acacia albida - based agroforestry practices in the Hararghe highlands of Eastern Ethiopia, Agroforest. Syst. 4, 129-143.

Radwanski S.A., Wickens G.E. (1967) The ecology of Acacia albida on mantle soils in Zalingei, Jebel Marra, Sudan, J. Appl. Ecol. 4, 469579.

Rayar A.J. (1983) University Farm Development Plan: Soil Survey, Department of Soil Science, University of Maiduguri, Nigeria.

Saka A.R., Bunderson W.T. (1989) The potential of Acacia albida and Leucaena leucacephala for smallholder crop production system in Malawi, in: Trees for Development in sub-Saharan Africa, Proceedings of Regional Seminar held by IFS, ICRAF, Kenya, pp. 150-161.

Sauerborn J. (1991) The economic importance of the phytoparasites Orobanche and Striga, in: Proceedings 5th International Symposium on Parasitic Weeds, in: Ransom J.K. (Ed.), CYMMT, Nairobi, pp. 137-143.

Sherif A.M., Parker C. (1986) Effect of nitrogen sources and organic matter on Sorghum bicolour (L.) Moench and Striga hermonthica Benth, Ethiopian J. Agr. Sci. 19, 19-35.

Weber F. (1978) Mid-point evaluation: Chad reforestation project, Prepared for CARE, Chad by Consultants in Development, Washington, DC (Mimeographed).

Wickens G. (1969) A study of Acacia albida Del. (Mimosoideae), Kew Bull. 23, 206-213.

Wilson A.K., Parker C. (1984) Techniques for setting up pot experiments involving the parasitic weed Striga, in: Parker C., Musselman L.J., Polhill R.M.,Wilson A.K. (Eds.), Proceedings 3rd International Symposium on Parasitic Weeds, ICARDA, Aleppo, Syria, pp. 133142.

Wood P.J. (1989) Faidherbia albida: A monographed, Paris. 